\title{
Optimal Monetary Policy Under a Global Dollar Standard: The Effect of Vertical Trade and Production
}

\author{
Chan Wang • Heng-fu Zou
}

Published online: 13 June 2014

(C) Springer Science+Business Media New York 2014

\begin{abstract}
This paper revisits Devereux et al. (J Int Econ 71:113-132 2007) which studies trade and macroeconomic behaviour in a two-country model under a reference currency such as the dollar in US-China trade. The home country (e.g. the US) sets its export prices in dollars and so does the foreign country (e.g. China), so that the US has Local Currency Pricing (LCP) of its imports while China has Producer Currency Pricing (PCP) of its imports. We crucially modify their model by adding the large and by now well-known trade in intermediate goods. The addition implies that there is now exchange-rate pass-through via intermediate-goods markets into US import prices which thereby become to some degree PCP like China; accordingly monetary expansion in the US now produces not merely an expansion effect in both countries but also an expenditure-switching effect towards itself by lowering its exchange rate and so raising the relative US consumer prices of Chinese goods. This modification has implications for the effects of monetary policy in both countries.
\end{abstract}

Keywords Vertical production and trade · Reference-currency pricing · Optimal monetary policy $\cdot$ Exchange-rates pass-through

C. Wang $(\bowtie)$

Guanghua School of Management, Peking University, Beijing, 100871, China

e-mail: wangchanist@gmail.com

\section{H.-f. Zou}

China Economics and Management Academy, Central University of Finance and Economics,

Beijing, 100081, China

e-mail: Hzoucema@gmail.com

H.-f. Zou

Institute for Advanced Study, Wuhan University, Wuhan, 430072, China

H.-f. Zou

Institute for Advanced Study, Shenzhen University, Shenzhen, 518060, China 
JEL Classification: E5 $\cdot$ F3 $\cdot$ F4

\section{Introduction}

The integration of the global economy is becoming increasingly characterized by vertical production and trade processes. This means that producers in a country not only use domestic but also foreign intermediate goods to produce final goods, which are in turn consumed by both home and foreign households. Using input-output tables from 10 OECD and four emerging market countries, Hummels et al. (2001) find that vertical specialization accounts for $21 \%$ of these countries' exports, and has grown almost $30 \%$ between 1970 and 1990. In addition, Feenstra (1998), Hummels et al. (1998), Yi (2003, 2010), and Bridgman (2012) also emphasize the importance of vertical production and trade in the development of the world economy.

Another important fact is that the US dollar plays a dominant role in the world economy; this has received limited attention in the literature. Using quarterly data for 23 OECD countries from 1975 to 2003, Campa and Goldberg (2005) provide crosscountry and time-series evidence on the extent of pass-through into import prices. They find that the US has the lowest pass-through rate among OECD countries. Gopinath and Rigobon (2008) use dock-side micro data on U.S. import and export prices for the period 1994-2005 and find that there is producer currency pricing in US exports and local currency pricing in US imports. Goldberg and Tille (2008, 2009) provide the empirical evidence that clearly highlights the global role of the dollar. They find that the dollar is used in the invoicing of trade not only between US and its trading partners but also between trading partners that have nothing to do with US. In addition, Shi and Xu (2010) study the problem of twin dollarization which is motivated by the observation that East Asian economies not only borrow bonds denominated in US dollars but also price their export goods in US dollars. In Devereux et al. (2007), the US dollar plays the role of the reference currency in which both home and foreign exporters set their prices.

How does vertical production and trade affect pricing behaviour in an economy with a reference currency? To answer this question, we revisit Devereux et al. (2007) and introduce vertical production and trade in line with Obstfeld (2002), Huang and Liu (2006), Devereux and Engel (2007), Shi and Xu (2007). In addition, following Obstfeld (2002), Devereux and Engel (2007), we assume that final-goods prices are sticky, but intermediate-goods prices are flexible, which is supported by a large empirical literature ${ }^{1}$; we also assume that wages are sticky, as is widely assumed in the macro literature. A striking feature of Devereux et al. (2007) is that, because of the reference currency feature, the home country (i.e. the US) has zero exchange-rate pass-through whereas the foreign country (i.e. China) has complete exchange-rate pass-through. By introducing vertical production and trade and assuming flexible

\footnotetext{
${ }^{1}$ A nonexhaustive list includes: Murphy et al. (1989), Clark (1999), Bils and Klenow (2004), Nakamura and Steinsson (2008).
} 
intermediate-goods prices, we restore complete exchange-rate pass-through at the intermediate stage in the home country, the US. This is our essential modification of Devereux et al. (2007).

The modification has welfare implications for monetary policy. Our research follows the tradition initiated by Friedman (1953), Mundell (1961) and Feldstein (1992), according to whom, when nominal goods prices are sticky, freely floating exchange rates can achieve relative price adjustment between countries, dealing with real country-specific productivity or demand shocks. The tradition is further enriched by Dellas and Tavlas (2005) who find that the welfare consequences of monetary arrangements depend more on the degree of wage asymmetry than on other types of asymmetries. More recently, by combining intertemporal choice and nominal rigidities, Obstfeld and Rogoff (2000) propose a framework for analyzing optimal monetary policy rules in open economies, in which global monetary policy replicates the allocations under flexible wages and so achieves efficiency. Obstfeld and Rogoff (2002) generalize to the case with incomplete international asset markets. If the shocks are global, optimal monetary policy rules involve replicating the allocations under flexible wages, furthermore, there are no gains from cooperation. By comparison, if shocks are country specific, optimal monetary policy rules cannot replicate the allocations under flexible wages, and gains from cooperation, though quantitatively small, can arise.

However, the conclusions in Obstfeld and Rogoff $(2000,2002)$ are based on the assumption that exporters set prices in the currency of the producers (PCP). Devereux and Engel (2003) not only consider the PCP case but also the situation in which exporters set prices in consumers' currency (LCP). In the PCP case, optimal monetary policy rules can replicate flexible-price allocations, and a flexible exchange rate is optimal. By contrast, in the LCP case, optimal monetary policy rules cannot replicate flexible-price allocations and a fixed exchange rate is optimal. Building on Devereux and Engel (2003), Devereux et al. (2007) analyze the case in which both home and foreign exporters set prices in the reference currency. When the coefficient of relative risk aversion is unity, the foreign monetary policy maker, in China, responds only to its own country's shock, but its home (US) counterpart whose currency is the reference currency responds to both home and foreign shocks. Surprisingly, they find that, in a Nash equilibrium, the home (US) household's expected utility is always lower than that of its foreign (China) counterpart.

However, when we modify Devereux et al. (2007) to give complete exchange-rate pass-through at intermediate stage in the home (US), the monetary policy prescriptions are different; we also modify the circumstances in which the surprising result in Devereux et al. (2007) for home household utility occurs. In general our model makes the US a relatively 'normal' country again, with a degree of exchange rate pass-through. This restores to it a normal monetary policy and also removes any gains from monetary cooperation.

The paper is organized as follows. Section 2 presents the basic model. Section 3 describes the equilibrium under flexible prices and wages. Section 4 approximates the equilibrium system and consumer welfare in both countries. Section 5 solves for optimal monetary policy rules. Section 6 concludes. 


\section{The Model}

Our model is built on Devereux et al. (2007) which is an extension to Devereux and Engel (2003). A striking feature in Devereux et al. (2007) is that the home country (US) has zero exchange-rate pass-through, however, the foreign country (China) has complete exchange-rate pass-through. We modify it by introducing vertical production and trade in line with Obstfeld (2002), Huang and Liu (2006), Devereux and Engel (2007), Shi and Xu (2007) and assuming flexible intermediate-goods prices which is evidenced by a large empirical literature. ${ }^{2}$

The model's structure is similar to that of Shi and Xu (2007). There are two countries, home $H$ and foreign $F$. Both home final and intermediate goods have a measure $n$, which also measures home population. For the foreign, the measure is $1-n$. The production is integrated by two stages in each country: one produces the tradable final goods which use both home and foreign intermediate goods as inputs and are consumed by households in the world; the other produces the tradable intermediate goods using only domestic labor as input. Home currency is used as the reference currency which means both home and foreign exporters use it to price their goods, no matter which stages they come from. In addition, we assume that wages are sticky. ${ }^{3}$ Thus, there is exchange-rate pass-through in the intermediate-goods markets for the home and foreign. 4

For clarity, we describe the timing of the model. There is only a single period which is divided into two sub-periods by shocks. Before the realization of the shocks, households trade in a complete set of state-contingent bonds denominated in the home currency; next, monetary authorities announce monetary policy rules to the public; final-goods producers and households then set prices and wages respectively. After the realization of the shocks, intermediate-goods producers set prices, labor is employed, production and consumption take place, and the exchange rate is determined.

In the following, asterisks denote foreign variables, lower-case letter $f$ denotes the final good, $i$ the intermediate good.

\footnotetext{
${ }^{2}$ Among many others, Murphy et al. (1989) and Clark (1999) show that for the aggregate US PPI, intermediate goods especially raw materials are much more volatile than final goods. Bils and Klenow (2004) estimate that the price of raw goods is 3-4 times more volatile than that of processed goods. Nakamura and Steinsson (2008) estimate that final-goods prices are more sticky than intermediate goods.

${ }^{3}$ The assumption is widely accepted in macro literature. Among many others, a nonexhaustive list includes: Taylor (1999), Erceg et al. (2000), Obstfeld and Rogoff (2000, 2002), Obstfeld (2002), Christiano et al. (2005), Hall (2005), Dellas and Tavlas (2005), Blanchard and Gali (2007, 2010), Erceg et al. (2010), Grohe and Uribe (2012), Gali and Monacelli (2013), Farhi et al. (2014).

${ }^{4}$ Obstfeld (2002) also considers the case in which exchange-rate pass-through occurs in the intermediategoods markets. But in his model, there is no trade in final goods, and exporters set prices in the currency of the producers.
} 


\subsection{Households}

A home representative household $h \in[0, n]$ maximizes the following expected utility:

$$
U=E\left(\ln C+\chi \ln \frac{M}{P}-\eta L\right),
$$

in which $\frac{M}{P}$ is real money balances, $L$ is labor supply, $\chi$ is a positive parameter, $\eta$ is a country-specific shock to the disutility of labor effort satisfying $E(\ln \eta)=0$ and $\operatorname{Var}(\ln \eta)=\sigma_{\eta}^{2}$. As explained in Obstfeld and Rogoff $(1995,2000,2002), \eta$ can be interpreted as a negative labor productivity shock. ${ }^{5}$ Real consumption index $C$ is an Armington aggregate of home and foreign final-composite goods,

$$
C=\frac{C_{H}^{n} C_{F}^{1-n}}{n^{n}(1-n)^{1-n}}
$$

where $C_{H}=\left[n^{-\frac{1}{\lambda}} \int_{0}^{n} C_{H}\left(j_{f}\right)^{\frac{\lambda-1}{\lambda}} d j_{f}\right]^{\frac{\lambda}{\lambda-1}}$ is an aggregate of the home final goods indexed by $j_{f} \in[0, n], C_{F}=\left[(1-n)^{-\frac{1}{\lambda}} \int_{n}^{1} C_{F}\left(j_{f}^{*}\right)^{\frac{\lambda-1}{\lambda}} d j_{f}^{*}\right]^{\frac{\lambda}{\lambda-1}}$ denotes the foreign counterpart of $C_{H}$. The parameter $\lambda(\lambda>1)$ is the elasticity of substitution between varieties of the final goods within each country. Thus, home price index over $C$ is

$$
P=P_{H H f}^{n} P_{F H f}^{1-n},
$$

where $P_{H H f}$ and $P_{F H f}$ represent price subindexes of the home and foreign finalcomposite goods respectively. Its foreign counterpart is

$$
P^{*}=\left(\frac{P_{H F f}}{S}\right)^{n}\left(P_{F F f}^{*}\right)^{1-n} .
$$

The home representative household $h \in[0, n]$ faces the following budget constraint:

$$
P C+M+\sum_{z \in Z} q(z) B(z)=W(h) L(h)+\Pi+B+M_{0}+T,
$$

where $z$ represents a particular natural state, $Z$ is the set of all states, $B(z)$ is the amount of bonds held by the household which entitles her to be paid $B$ units of home currency, $q(z)$ is the home price of the state-contingent bond, $W(h)$ denotes the wage level set by the household, $L(h)$ represents the labor demands by home

\footnotetext{
${ }^{5}$ For foreign labor productivity shock $\eta^{*}$, the same properties hold: $E\left(\ln \eta^{*}\right)=0, \operatorname{Var}\left(\ln \eta^{*}\right)=\sigma_{\eta^{*}}^{2}$.
} 
intermediate-goods producers, $\Pi$ is the profits from the ownership of home firms which distribute their profits among domestic households equally, $T$ denotes the net government transfer, i.e. the difference between a lump-sum government transfer and a lump-sum tax. Lump-sum government transfer is financed by government's seigniorage revenue $M-M_{0}$, lump-sum tax is levied to subsidize domestic firms and households to eliminate distortions associated with monopolistic competition.

The home representative household's optimality conditions can be obtained by solving her time-0 problem. Money demand function is

$$
M=\chi P C .
$$

The above equation ensures that the marginal utility from holding an extra unit of money equals the marginal cost measured by forgone consumption.

The trade in the state-contingent bonds between home and foreign households leads to the following risk-sharing condition:

$$
\Gamma P C=S P^{*} C^{*},
$$

where $S$ is the nominal exchange rate representing the home currency price of one unit of foreign currency. $\Gamma$ is the ratio of the home and foreign households' Lagrange multipliers and is determined by an equilibrium condition in the market for the statecontingent bonds. As shown in the appendix of Devereux and Engel (2003), $\Gamma=1$ holds when log utility function of consumption is assumed. However, it is noteworthy that, in general, $\Gamma$ differs from 1 to reflect the difference between the home and foreign which results from the asymmetry in exporters' pricing behaviour. ${ }^{6}$

Wages are sticky for one period and set before the shocks are realized. The representative household $h \in[0, n]$ will set the nominal wage:

$$
W=\frac{E(\eta L)}{E\left(\frac{L}{P C}\right)} .
$$

The wage-setting equation requires that, at an optimum, the expected marginal utility of consumption from lowering the wage slightly must equal the expected marginal disutility from additional labor hours. Notice that the household $h^{\prime} s$ monopoly power is eliminated by government's subsidy which is equal to $\frac{1}{\theta-1}$ in amount. The expression for the household $h^{\prime} s$ labor demand will be explicit when the description of production processes is completed.

\subsection{Firms}

The home final goods are produced by a continuum of firms indexed by $j_{f} \in[0, n]$ with the following production function:

$$
Y_{H f}\left(j_{f}\right)=\frac{\theta_{f} Y_{H i}\left(j_{f}\right)^{\varepsilon} Y_{F i}\left(j_{f}\right)^{1-\varepsilon}}{\varepsilon^{\varepsilon}(1-\varepsilon)^{1-\varepsilon}},
$$

\footnotetext{
${ }^{6} \mathrm{~A}$ more general case in which $\Gamma$ differs from 1 is considered in Devereux et al. (2007).
} 
in which $\theta_{f}$ is the productivity shock at home final-goods stage satisfying $E\left(\ln \theta_{f}\right)=0$ and $\operatorname{Var}\left(\ln \theta_{f}\right)=\sigma_{\theta_{f}}^{2}{ }^{7} Y_{H} i\left(j_{f}\right)$ represents the input of home intermediate composite which is defined as

$$
Y_{H i}\left(j_{f}\right)=\left[n^{-\frac{1}{\phi}} \int_{0}^{n} Y_{H i}\left(j_{f}, j_{i}\right)^{\frac{\phi-1}{\phi}} d j_{i}\right]^{\frac{\phi}{\phi-1}}, \phi>1 .
$$

$Y_{F i}\left(j_{f}\right)$, the input of foreign intermediate composite, is analogously defined, but over a range of foreign intermediate goods indexed by $j_{i}^{*} \in[n, 1]$.

The unit cost function of a home representative firm $j_{f} \in[0, n]$ is $C\left(P_{H H i}, P_{F H i}\right)=\frac{P_{H H i}^{\varepsilon} P_{F H i}^{1-\varepsilon}}{\theta_{f}}$, where $P_{H H i}\left(P_{F H i}\right)$ is the price index of home (foreign) intermediate goods. The demands for home and foreign intermediate goods $j_{i}$ and $j_{i}^{*}$ from the home representative firm $j_{f} \in[0, n]$ are respectively

$$
\begin{gathered}
Y_{H i}\left(j_{f}, j_{i}\right)=\frac{\varepsilon}{n}\left(\frac{P_{H H i}\left(j_{i}\right)}{P_{H H i}}\right)^{-\phi}\left(\frac{P_{H H i}}{C\left(P_{H H i}, P_{F H i}\right)}\right)^{-1} Y_{H f}\left(j_{f}\right), \\
Y_{F i}\left(j_{f}, j_{i}^{*}\right)=\frac{1-\varepsilon}{1-n}\left(\frac{P_{F H i}\left(j_{i}^{*}\right)}{P_{F H i}}\right)^{-\phi}\left(\frac{P_{F H i}}{C\left(P_{H H i}, P_{F H i}\right)}\right)^{-1} Y_{H f}\left(j_{f}\right) .
\end{gathered}
$$

The home intermediate goods are produced by a continuum of firms indexed by $j_{i} \in[0, n]$ with the following production function:

$$
Y_{H i}\left(j_{i}\right)=\left[n^{-\frac{1}{\theta}} \int_{0}^{n} L\left(h, j_{i}\right)^{\frac{\theta-1}{\theta}} d h\right]^{\frac{\theta}{\theta-1}}, \theta>1,
$$

in which $L\left(h, j_{i}\right)$ is the labor provided by the household $h$ which has the monopoly power over her variety of labor. Cost minimization implies that wage index is $W=$ $\left[\frac{1}{n} \int_{0}^{n} W(h)^{1-\theta} d h\right]^{\frac{1}{1-\theta}}$. And the demand for labor $h$ from the home intermediategood producer $j_{i}$ is $L\left(h, j_{i}\right)=\frac{1}{n}\left(\frac{W(h)}{W}\right)^{-\theta} Y_{H i}^{s}\left(j_{i}\right)$, in which $Y_{H i}^{s}\left(j_{i}\right)$ is the supply of the intermediate good $j_{i}$.

Firms at both stages choose prices to maximize their profits. Optimal prices are listed in Table 1. Notice the final-goods producers set prices in advance and the intermediate-goods producers after the realization of the shocks. In addition, both the final and intermediate-goods producers receive the production subsidies from the government. As a result, price markups equal 1 at both stages.

\footnotetext{
${ }^{7}$ For the foreign productivity shock at the final stage $\eta^{*}$, we also have $E\left(\ln \theta_{f}^{*}\right)=0$ and $\operatorname{Var}\left(\ln \theta_{f}^{*}\right)=$ $\sigma_{\theta_{f^{*}}}^{2}$.
} 
Table 1 Optimal Prices

\begin{tabular}{ll}
\hline$P_{H H f}=E\left(\frac{P_{H H i}^{\varepsilon} P_{F H i}^{1-\varepsilon}}{\theta_{f}}\right)$ & $P_{H F f}=E\left(\frac{P_{H H i}^{\varepsilon} P_{F H i}^{1-\varepsilon}}{\theta_{f}}\right)$ \\
$P_{F H f}=E\left(S \frac{\left(\frac{P_{H F i}}{S}\right)^{\varepsilon}\left(P_{F F i}^{*}\right)^{1-\varepsilon}}{\theta_{f}^{*}}\right)$ & $P_{F F f}^{*}=E\left(\frac{\left(\frac{P_{H F i}}{S}\right)^{\varepsilon}\left(P_{F F i}^{*}\right)^{1-\varepsilon}}{\theta_{f}^{*}}\right)$ \\
$P_{H H i}=W$ & $P_{H F i}=W$ \\
$P_{F H i}=S W^{*}$ & $P_{F F i}^{*}=W^{*}$ \\
\hline
\end{tabular}

\section{Equilibrium Under Flexible Prices and Wages}

We first solve the equilibrium under flexible prices and wages as a benchmark. In this case, the wage-setting condition (5) is replaced by $W=\eta P C$, the optimal prices chosen by the firms at the final stage are the same as those in Table 1 except that the expectation operators are left off.

Market-clearing condition in the home is

$$
\begin{aligned}
& L=\frac{\varepsilon}{n} \frac{C\left(P_{H H i}, P_{F H i}\right)}{P_{H H i}}\left(n^{2} \frac{P C}{P_{H H f}}+n(1-n) \frac{S P^{*} C^{*}}{P_{H F f}}\right)+ \\
& \frac{\varepsilon}{n} \frac{S C^{*}\left(\frac{P_{H F i}}{S}, P_{F F i}^{*}\right)}{P_{H F i}}\left(n(1-n) \frac{P C}{P_{F H f}}+(1-n)^{2} \frac{P^{*} C^{*}}{P_{F F f}^{*}}\right),
\end{aligned}
$$

in which $C^{*}\left(\frac{P_{H F i}}{S}, P_{F F i}^{*}\right)=\frac{\left(\frac{P_{H F i}}{S}\right)^{\varepsilon}\left(P_{F F i}^{*}\right)^{1-\varepsilon}}{\theta_{f}^{*}}$ is the unit cost facing a foreign representative firm at the final stage. The first term on the right-hand side of the above equation represents the demands for labor from the home intermediate-goods firms whose products are used as inputs by the home final-goods firms; the second term is the demands for labor from the home intermediate-goods firms whose products are used as inputs by the foreign final-goods firms.

Since $M$ and $M^{*}$ are chosen by home and foreign monetary authorities respectively, $\theta_{f}, \theta_{f}^{*}, \eta, \eta^{*}$ are the exogenous shocks, the equilibrium under flexible prices and wages consists of 17 equations: 8 pricing equations, 2 money demand equations, 2 wage-setting equations, 2 price indexes, 1 risk-sharing condition, 2 market-clearing conditions. Thus, 17 endogenous variables $P_{H H f}, P_{H F f}, P_{F H f}, P_{F F f}^{*}, P_{H H i}$, $P_{H F i}, P_{F H i}, P_{F F i}^{*}, S, W, W^{*}, P, P^{*}, C, C^{*}, L, L^{*}$ can be determined.

Since both the prices and wages are flexible, the law of one price holds, the asymmetry in pricing would be irrelevant. The home representative household's consumption is equal to her foreign counterpart,

$$
\widetilde{C}=\widetilde{C^{*}}=\theta_{f}^{n} \theta_{f}^{*^{1-n}} \eta^{-\varepsilon} \eta^{*^{-(1-\varepsilon)}},
$$

in which a variable with a tilde denotes the value under the flexible prices and wages. The previous equation implies that a positive productivity shock will increase consumption, no matter which country it comes from. 
The home employment is given by $\widetilde{L}=\frac{\varepsilon}{n} \frac{1}{\eta}$, as a comparison, its foreign counterpart is $\widetilde{L^{*}}=\frac{1-\varepsilon}{1-n} \frac{1}{\eta^{*}}$.

\section{Solving the Model}

Since it is impossible to derive the model's closed-form solution when both finalgoods prices and wages are sticky, we adopt the method used in Sutherland (2002) and log-linearize the equilibrium system whereas approximate the welfare around the non-stochastic steady state up to a second order. The non-stochastic steady state results when $\theta_{f}=\theta_{f}^{*}=\eta=\eta^{*}=1$.In the following, a variable $X$ with a hat denotes the $\log$-deviation from its non-stochastic steady state $\bar{X}$, i.e. $\widehat{X}=\log \left(\frac{X}{\bar{X}}\right)$.

From the approximation to the money demand functions and the risk-sharing condition, we have

$$
\widehat{S}=\widehat{M}-\widehat{M^{*}}+O\left(\|\xi\|^{2}\right),
$$

in which $O\left(\|\xi\|^{n}\right)$ is a residual containing all terms of order higher than $n$. Thus, if the home monetary authority releases more money than its foreign counterpart, Eq. 7 implies that the home currency will depreciate.

The wage indexes can be approximated as

$$
\begin{aligned}
\widehat{W} & =E(\widehat{\eta}+\widehat{M})+O\left(\|\xi\|^{2}\right), \\
\widehat{W^{*}} & =E\left(\widehat{\eta^{*}}+\widehat{M^{*}}\right)+O\left(\|\xi\|^{2}\right) .
\end{aligned}
$$

The money demand functions are used in the derivation of Eqs. 8 and 9. The intuition behind Eqs. 8 and 9 is that the household will set a higher wage if she expects that the monetary authority in her country pursues a looser monetary policy and if a larger disutility is incurred to offer one unit of labor.

Using the approximation to the final-goods prices, Eqs. 8 and 9, the consumer price indexes in the home and foreign can be approximated as respectively

$$
\begin{gathered}
\widehat{P}=\varepsilon E(\widehat{\eta}+\widehat{M})+(1-\varepsilon) E\left(\widehat{\eta^{*}}+\widehat{M^{*}}\right)+n E\left((1-\varepsilon) \widehat{S}-\widehat{\theta_{f}}\right) \\
+(1-n) E\left((1-\varepsilon) \widehat{S}-\widehat{\theta_{f}^{*}}\right)+O\left(\|\xi\|^{2}\right), \\
\widehat{P^{*}}=\varepsilon E(\widehat{\eta}+\widehat{M})+(1-\varepsilon) E\left(\widehat{\eta^{*}}+\widehat{M^{*}}\right)+n E\left((1-\varepsilon) \widehat{S}-\widehat{\theta_{f}}\right) \\
-(1-n) E\left(\varepsilon \widehat{S}+\widehat{\theta_{f}^{*}}\right)-n \widehat{S}+O\left(\|\xi\|^{2}\right) .
\end{gathered}
$$

The monetary policy can influence CPI by affecting the home and foreign wagesetters' expectations. In addition, it can also influence by the expenditure-switching effect in the intermediate-goods markets. An expected positive productivity shock, no matter which country it comes from, will lower CPI. 
From the money demand functions and Eqs. 10 and 11, we know $\widehat{C}$ can be expressed as a function of the monetary policies and the exogenous shocks. So can $\widehat{C^{*}}$ be.

Combining the home money-demand function and the wage-setting condition, we can approximate the home market-clearing condition as the following:

$$
\begin{gathered}
\widehat{L}=\widehat{M}-E(\widehat{\eta}+\widehat{M})+\left[n(1-\varepsilon)+n(1-n)(1-\varepsilon)-\varepsilon(1-n)^{2}\right](\widehat{S}-E \widehat{S}) \\
-n\left(\widehat{\theta_{f}}-E \widehat{\theta_{f}}\right)-(1-n)\left(\widehat{\theta_{f}^{*}}-E \widehat{\theta_{f}^{*}}\right)+O\left(\|\xi\|^{2}\right) .
\end{gathered}
$$

An increase in the home expenditure will increase the demands for the home and foreign final goods. The final-goods producers in both countries will, then, input more home intermediate goods. Consequently, the demands for the home labor increase. A higher wage set by the home household will lower the demands for her labor. If a home productivity shock at the final stage is greater than its expectation, the demands for the home labor will decrease. The same analysis applies for a foreign productivity shock at the final stage. The term involving the nominal exchange rate in Eq. 12 includes the combined effects: the demands for the home intermediate goods from the home final-goods producers whose goods are consumed by the home and foreign households; the demands for the home intermediate goods from the foreign final-goods producers supplying in both home and foreign markets.

Similarly, the foreign market-clearing condition is approximated as

$$
\begin{aligned}
\widehat{L^{*}}= & \widehat{M^{*}}-E\left(\widehat{\eta^{*}}+\widehat{M^{*}}\right)+\left[n(1-\varepsilon)+n(1-n)(1-\varepsilon)-\varepsilon(1-n)^{2}\right] \\
& (\widehat{S}-E \widehat{S})-n\left(\widehat{\theta_{f}}-E \widehat{\theta_{f}}\right)-(1-n)\left(\widehat{\theta_{f}^{*}}-E \widehat{\theta_{f}^{*}}\right)+O\left(\|\xi\|^{2}\right) .
\end{aligned}
$$

The intuition behind Eq. 13 is the same as that behind Eq. 12 .

Though it is enough to take the first-order approximation to the equilibrium system, we need to take the second-order approximation to the utility functions. Following the literature, we assume that the utility of the real balances is small enough to be neglected. ${ }^{8}$ The home household's utility, thus, can be approximated as

$$
U=\bar{U}+E\left[\widehat{C}-\bar{\eta} \bar{L}\left(\widehat{L}+\widehat{\eta}+\frac{1}{2}(\widehat{L}+\widehat{\eta})^{2}\right)\right]+O\|\xi\|^{3} .
$$

From the expressions for $\widehat{C}$ and $\widehat{L}$, we know that the home utility depends on the volatility of the exchange rate. In Devereux et al.(2007), since there is no expenditureswitching effect in the home country, the home utility is independent of the volatility of the exchange rate. In our model, the introduction of vertical production and trade and the assumption of flexible intermediate-goods prices make the expenditure switching in the home country take effect at the intermediate-goods level. Conse-

\footnotetext{
${ }^{8}$ Among many others, some examples of the literature include: Obstfeld and Rogoff (1995, 2001, 2000, 2002), Betts and Devereux (2000), Sutherland (2002), Benigno and Benigno (2003), Devereux and Engel (2003), Corsetti and Pesenti (2001, 2005), Devereux et al.(2007), Shi and Xu (2007), Wang and Zou (2013). For an empirical estimate, see Cooley and Hansen (1989).
} 
quently, the home monetary policy maker will consider the effects of the exchange rate on home households. After substituting the expressions for $\widehat{C}$ and $\widehat{L}$ into the above equation and using Eq. 7, we have

$$
\begin{gathered}
U \bar{U}-\varepsilon E \widehat{\eta}-(1-\varepsilon) E \widehat{\eta^{*}}+n E \widehat{\theta_{f}}+(1-n) E \widehat{\theta_{f}^{*}} \\
-\frac{\varepsilon}{2 n} E\left\{\left(1+n(1-\varepsilon)+n(1-n)(1-\varepsilon)-\varepsilon(1-n)^{2}\right)(\widehat{M}-E \widehat{M})\right. \\
-\left(n(1-\varepsilon)+n(1-n)(1-\varepsilon)-\varepsilon(1-n)^{2}\right)\left(\widehat{M^{*}}-E \widehat{M^{*}}\right) \\
\left.+(\widehat{\eta}-E \widehat{\eta})-n\left(\widehat{\theta_{f}}-E \widehat{\theta_{f}}\right)-(1-n)\left(\widehat{\theta_{f}^{*}}-E \widehat{\theta_{f}^{*}}\right)\right\}^{2}+O\left(\|\xi\|^{3}\right) .
\end{gathered}
$$

For foreign, it is

$$
\begin{gathered}
=\overline{U^{*}}-\varepsilon E \widehat{\eta}-(1-\varepsilon) E \widehat{\eta^{*}}+n E \widehat{\theta_{f}}+(1-n) E \widehat{\theta_{f}^{*}} \\
-\frac{1-\varepsilon}{2(1-n)} E\left\{\left(n(1-\varepsilon)+n(1-n)(1-\varepsilon)-\varepsilon(1-n)^{2}\right)(\widehat{M}-E \widehat{M})\right. \\
+\left(1-n(1-\varepsilon)-n(1-n)(1-\varepsilon)+\varepsilon(1-n)^{2}\right)\left(\widehat{M^{*}}-E \widehat{M^{*}}\right) \\
\left.+\left(\widehat{\eta^{*}}-E \widehat{\eta^{*}}\right)-n\left(\widehat{\theta_{f}}-E \widehat{\theta_{f}}\right)-(1-n)\left(\widehat{\theta_{f}^{*}}-E \widehat{\theta_{f}^{*}}\right)\right\}^{2}+O\left(\|\xi\|^{3}\right) .
\end{gathered}
$$

\section{Optimal Monetary Policy Rules}

In line with Obstfeld and Rogoff (2002), Devereux and Engel (2003), Devereux et al.(2007), Shi and Xu (2007), we assume monetary policy rules are chosen with commitment in the sense that monetary authorities take account of the effects of their policy rules on household's expected consumption and employment, since their decisions can influence pre-set prices and wages. For concreteness, monetary policy rules are given by

$$
\begin{gathered}
\widehat{M}=a_{1} \widehat{\theta_{f}}+a_{2} \widehat{\theta_{f}^{*}}+a_{3} \widehat{\eta}+a_{4} \widehat{\eta^{*}}, \\
\widehat{M^{*}}=b_{1} \widehat{\theta_{f}}+b_{2} \widehat{\theta_{f}^{*}}+b_{3} \widehat{\eta}+b_{4} \widehat{\eta^{*}},
\end{gathered}
$$

Substituting Eqs. 16 and 17 into Eqs. 14 and 15 home and foreign utilities can be expressed as the functions of the shocks and the monetary feedback parameters. Since the non-stochastic steady state is efficient, home monetary authority chooses the feedback parameters $a=\left\{a_{1}, a_{2}, a_{3}, a_{4}\right\}$ to minimize the difference between $U$ and $\bar{U}$, taking the feedback parameters of its foreign counterpart $b=\left\{b_{1}, b_{2}, b_{3}, b_{4}\right\}$ as given. Foreign monetary authority also faces the same problem. In other words, home and foreign monetary policy makers play the following Nash game:

$$
\min _{a} U\left(a, b^{N}\right)-\bar{U} \quad \min _{b} U^{*}\left(a^{N}, b\right)-\overline{U^{*}}
$$


in which

$$
\begin{aligned}
U\left(a, b^{N}\right)-\bar{U} & =-\frac{\varepsilon}{2 n} E\left\{\widehat{\eta}-n \widehat{\theta_{f}}-(1-n) \widehat{\theta_{f}^{*}}+(1+n(1-\varepsilon)+n(1-n)\right. \\
& \left.(1-\varepsilon)-\varepsilon(1-n)^{2}\right)\left(a_{1} \widehat{\theta_{f}}+a_{2} \widehat{\theta_{f}^{*}}+a_{3} \widehat{\eta}+a_{4} \widehat{\eta^{*}}\right)-(n(1-\varepsilon) \\
& \left.\left.+n(1-n)(1-\varepsilon)-\varepsilon(1-n)^{2}\right)\left(b_{1} \widehat{\theta_{f}}+b_{2} \widehat{\theta_{f}^{*}}+b_{3} \widehat{\eta}+b_{4} \widehat{\eta^{*}}\right)\right\}^{2}
\end{aligned}
$$

and

$$
\begin{aligned}
U^{*}\left(a^{N}, b\right)-\overline{U^{*}}= & -\frac{1-\varepsilon}{2(1-n)} E\left\{\widehat{\eta^{*}}-n \widehat{\theta_{f}}-(1-n) \widehat{\theta_{f}^{*}}+(n(1-\varepsilon)\right. \\
& \left.+n(1-n)(1-\varepsilon)-\varepsilon(1-n)^{2}\right)\left(a_{1} \widehat{\theta_{f}}+a_{2} \widehat{\theta_{f}^{*}}+a_{3} \widehat{\eta}+a_{4} \widehat{\eta^{*}}\right) \\
& +\left(1-n(1-\varepsilon)-n(1-n)(1-\varepsilon)+\varepsilon(1-n)^{2}\right) \\
& \left.\left(b_{1} \widehat{\theta_{f}}+b_{2} \widehat{\theta_{f}^{*}}+b_{3} \widehat{\eta}+b_{4} \widehat{\eta^{*}}\right)\right\}^{2} .
\end{aligned}
$$

Solving problem (P1) we have

Proposition 1 The solution to problem $(P 1)$ is

$$
\begin{aligned}
& a_{1}=n, a_{2}=1-n, a_{3}=(n-\varepsilon)+n(1-n)-1, a_{4}=-[(n-\varepsilon)+n(1-n)], \\
& b_{1}=n, b_{2}=1-n, b_{3}=(n-\varepsilon)+n(1-n), b_{4}=-[1+(n-\varepsilon)+n(1-n)] .
\end{aligned}
$$

Proof See Technical Appendix. ${ }^{9}$

A few words are in order. Home monetary responses are the same as those in Devereux et al. (2007) to the home and foreign productivity shocks at the final stage. However, foreign monetary responses are modified after we allow for the expenditure-switching effect at the intermediate-goods level. In Devereux et al. (2007), optimal foreign monetary responses to the home and foreign productivity shocks are $b_{1}=0, b_{2}=1$ respectively. The reason for the difference between our conclusion and theirs is, in our model, home monetary response to the home productivity shock at the final stage causes an additional negative externality to the foreign country. Concretely, when there is a positive productivity shock at the home final-goods stage, home monetary policy maker's optimal response is to loosen money supply to boost the demands for home final goods. However, in Devereux et al. (2007), home monetary policy can only achieve expenditure-level effect but no expenditure-switching effect. As a result, home households will increase the demands for home and foreign final goods simultaneously. Since there is complete exchangerate pass-through in the foreign country, foreign households will substitute home for foreign final goods. Net effect on foreign final goods are zero. Therefore, it is not necessary for the foreign monetary policy maker to take action. In our model, the situation is different. Though the previous analysis still holds, there is something new in the intermediate-goods markets. After the devaluation of the home currency, home intermediate goods are cheaper in the foreign country whereas foreign intermediate

\footnotetext{
${ }^{9}$ Which is available upon request.
} 
goods are more expensive in the home. The substitution of home for foreign intermediate goods by home and foreign final-goods producers produces an additional negative externality to the foreign country. Hence, foreign monetary policy maker responds by loosening money supply to balance the negative externality.

As far as the labor productivity shocks are concerned, in the limit case (a closed economy): as $n \rightarrow 1, \varepsilon \rightarrow 1$, optimal monetary policy is procyclical. In general case, optimal monetary policy rules depend on the magnitude of $\varepsilon$, the expenditure share of the home final-goods producers on the home intermediate goods. Concretely, when $0<\varepsilon<n+n(1-n)$, optimal monetary response parameters are respectively: $a_{3}<0, a_{4}<0, b_{3}>0, b_{4}<0$; when $n+n(1-n)<\varepsilon<1$, they are respectively: $a_{3}<0, a_{4}>0, b_{3}<0, b_{4}<0$.Thus, home monetary policy maker responds to a positive labor productivity shock in its own country by increasing money supply. The conclusion is independent of the value of $\varepsilon$. The reason is simple. When a positive labor productivity shock occurs in the home country, home monetary policy maker depreciates its currency to encourage home and foreign final-goods producers to switch the demands to the home intermediate goods. However, foreign monetary policy maker's response to a positive labor productivity shock in the home country does depend on the value of $\varepsilon$. When $0<\varepsilon<n+n(1-n)$, foreign monetary policy maker tightens its money supply, when $n+n(1-n)<\varepsilon<1$, it loosens its money supply. When $\varepsilon$ is small in magnitude, the devaluation of the home currency has a small effect on the foreign final-goods producers and a large effect on the home final-goods producers, and the expenditure-switching effect mainly occurs in the home intermediate-goods markets. Thus, foreign monetary policy maker decreases its money supply to devaluate the home currency further to boost the demands for the home final goods from the foreign households. By comparison, when $\varepsilon$ is large in magnitude, the devaluation of the home currency has a large effect on the foreign final-goods producers and a small effect on the home final-goods producers, and the expenditure-switching effect mainly occurs in the foreign intermediate-goods markets. Hence, foreign monetary policy maker increases its money supply to balance the home currency devaluation to ensure the foreign households to demand more of their own country's final goods. The case in which there is a positive labor productivity shock in the foreign country can be analyzed similarly.

In Devereux et al. (2007), when the utility function of consumption is logarithmic, home expected utility is independent of the foreign monetary policy. The reason is that there is no expenditure-switching role of the exchange rate in the home country when exporters in both countries set prices in terms of the home currency and the expected disutility of labor is a constant. By comparison, in our model in which only logarithmic utility of consumption is considered, the second-order term of the employment is vital to determine the optimal monetary policy rules. When there is expenditure-switching role of the exchange rate in both countries' intermediategoods markets, foreign monetary policy influences home welfare by means of the exchange rate which affects directly the export prices of the home and foreign intermediate goods and the prices of the home final goods sold in the foreign country, and eventually affects the demands for the home labor.

It is usually believed that US gains much from its ability to maintain the right to issue a global currency. When only considering US dollar's role as the international 
reference currency, Devereux et al. (2007) obtain a surprising result: in a Nash equilibrium, the home country's expected utility is always lower than that of the foreign. The reason is, as explained by them, foreign monetary policy maker can achieve both the expenditure-level and expenditure-switching effects. By contrast, home monetary policy maker can only resort to the expenditure-level role of its policy. Exchange-rate pass-through in the home country is nil. Therefore, unlike the foreign, home output can not be efficiently adjusted to the home and foreign productivity shocks. Home household's expected utility is always lower than his foreign counterpart.

In our model, though home monetary policy maker can not achieve the expenditure-switching effect in the final-goods markets, it can achieve in the intermediate-goods markets. Thus, compared with Devereux et al. (2007), it is expected the presence of the expenditure-switching effect in the home intermediategoods markets will improve home household's welfare.

Proposition 2 In a Nash equilibrium, if $\frac{1-n}{n}>\frac{1-\varepsilon}{\varepsilon}$, then home household's expected utility is lower than that of her foreign counterpart; if $\frac{1-n}{n}<\frac{1-\varepsilon}{\varepsilon}$, then home household's expected utility is greater than that of her foreign counterpart; if $\frac{1-n}{n}=\frac{1-\varepsilon}{\varepsilon}$, then home household's expected utility is identical to that of her foreign counterpart.

Proof In a Nash equilibrium, the expected utility of the home representative household is

$$
U=E\left[\ln \left(\theta_{f}^{n} \theta_{f}^{*^{(1-n)}} \eta^{((n-\varepsilon)+n(1-n)-1)} \eta^{*^{-((n-\varepsilon)+n(1-n))}}\right)-\frac{\varepsilon}{n}\right],
$$

its foreign counterpart is

$$
U^{*}=E\left[\ln \left(\theta_{f}^{n} \theta_{f}^{*^{(1-n)}} \eta^{\left((n-\varepsilon)-n^{2}\right)} \eta^{*^{-\left(1+(n-\varepsilon)-n^{2}\right)}}\right)-\frac{1-\varepsilon}{1-n}\right] .
$$

By assumptions that $E\left(\ln \theta_{f}\right)=E\left(\ln \theta_{f}^{*}\right)=E(\ln \eta)=E\left(\ln \eta^{*}\right)=0$, Eqs. 18 and 19 can be reduced to $U=-\frac{\varepsilon}{n}$ and $U^{*}=-\frac{1-\varepsilon}{1-n}$ respectively. Thus, when $\frac{1-n}{n}>$ $\frac{1-\varepsilon}{\varepsilon}$, then $U<U^{*}$; when $\frac{1-n}{n}<\frac{1-\varepsilon}{\varepsilon}$, we have $U>U^{*}$; when $\frac{1-n}{n}=\frac{1-\varepsilon}{\varepsilon}, U=U^{*}$ follows.

Intuitively, for the home country, when welfare gains from the presence of the expenditure-switching function of the exchange rate in the intermediate-goods markets exceed welfare losses in the final-goods markets, the home household becomes better off. The more the input of foreign intermediate goods is than that of home intermediate goods in the production of home final goods, the larger the welfare gains are. In other words, the larger the ratio $\frac{1-\varepsilon}{\varepsilon}$ is, the better off the home household is. By the same logic, the smaller the ratio $\frac{1-n}{n}$ is, the less the welfare losses are. When $\frac{1-n}{n}<\frac{1-\varepsilon}{\varepsilon}$, the home household enjoys a positive net welfare in our model which contrasts sharply with Devereux et al. (2007) in which the home household experiences welfare losses but no gains from home currency's role of being the reference currency. For the foreign country, a larger ratio $\frac{1-\varepsilon}{\varepsilon}$ implies that welfare gains are 
less from the expenditure-switching role of the exchange rate in the intermediategoods markets. Similarly, a smaller ratio $\frac{1-n}{n}$ means welfare gains are larger from the expenditure-switching role of the exchange rate in the final-goods markets. However, when $\frac{1-n}{n}<\frac{1-\varepsilon}{\varepsilon}$, the expenditure-switching role of the exchange rate in the intermediate-goods markets dominates that in the final-goods markets. Comparing with her home counterpart, the foreign household is worse off. Other cases can be analyzed similarly.

A noticeable point in our model is that, in a Nash equilibrium, both the home and foreign households can achieve the same expected utilities as those under flexible prices and wages. This implies

Proposition 3 There are no gains from monetary policy cooperation.

Among many others, the same conclusion is also found in Obstfeld and Rogoff (2000, 2002), Clarida, Gali and Gertler (2002), Devereux and Engel (2003), Corsetti and Pesenti (2005), Shi and Xu (2007).

\section{Conclusion}

In this paper, we revisit Devereux et al. (2007) and discuss optimal monetary policy under a dollar standard. But we deviate from Devereux et al. (2007) in which exchange-rate pass-through is zero in the home country but complete in the foreign by introducing the exchange rate pass-through in the home at the intermediate stage. Specifically, we consider a vertical production and trade structure in which finalgoods prices are sticky whereas intermediate-goods prices are flexible. Since wages are set before the realization of the shocks, and the production of the intermediate goods uses labor as the sole input, the exchange-rate pass-through is introduced for both countries at the intermediate stage.

We find that home monetary responses remain the same as those in Devereux et al. (2007) to the home and foreign productivity shocks at the final stage. However, foreign monetary response to a positive home productivity shock at the final stage is different. When it occurs, in Devereux et al. (2007), foreign monetary policy maker takes no action. As a comparison, in our model, foreign monetary policy maker expands money supply. The reason is that the exchange-rate pass-through at the intermediate stage diverts the demands for the intermediate goods to the home in both countries and thus produces an additional negative externality to the foreign. To balance the negative externality, foreign monetary policy maker expands money supply.

We also find that home monetary policy maker responds to a positive labor productivity shock in its own country by increasing money supply. However, its foreign counterpart's response depends on the value of $\varepsilon$, the expenditure share of the home intermediate goods in the production of the home final goods. Similarly, foreign monetary policy maker expands money supply as a response to a positive labor productivity shock in its own country. Its home counterpart's response, however, depends on the value of $\varepsilon$. 
A surprising result in Devereux et al. (2007) is, in a Nash equilibrium, home country's expected utility is always lower than that of the foreign. The reason is, unlike the foreign, the expenditure-switching effect of home monetary policy disappears. After we introduce the expenditure-switching effect for both countries at the intermediate stage, their conclusion is greatly revised. When relative expenditure share of the foreign to home intermediate goods in the production of the home final goods is greater than relative expenditure share of foreign to home final goods in the home household's consumption, home household's expected utility is higher than that of the foreign. When the former is smaller than the latter, the conclusion of Devereux et al. (2007) still holds.

Acknowledgments We thank the editor, George S. Tavlas, and an anonymous referee for very helpful comments. In addition, we thank Liutang Gong, Xiaoyong Cui, Jiandong Ju, Juanyi Xu, Feng Shi, Wei Tu, Tan Cheng, Changlin Luo, Jingguo Yang, Hongkui Liu, Cheng Guo for useful suggestions. We also thank seminar participants of Macro Group at GSM.

\section{References}

Benigno G, Benigno P (2003) Price stability in open economies. Rev Econ Stud 70:743-764

Betts C, Devereux MB (2000) Exchange rate dynamics in a model of pricing-to-market. J Int Econ 50:215244

Bils M, Klenow PJ (2004) Some evidence on the importance of sticky prices. J Polit Econ 112:947-985

Blanchard OJ, Gali J (2007) Real wage rigidities and the New Keynesian Model. J Money Credit Bank, supplement to 39(1):35-66

Blanchard OJ, Gali J (2010) Labor markets and monetary policy: a New Keynesian model with unemployment. Am Econ J: Macroecon 2(2):1-33

Bridgman B (2012) The rise of vertical specialization trade. J Int Econ 86:133-140

Campa JM, Goldberg LS (2005) Exchange rate pass through into import prices. Rev Econ Stat 87:679-690

Christiano LJ, Eichenbaum M, Evans CL (2005) Nominal rigidities and the dynamic effects of a shock to monetary policy. J Polit Econ 113(1):1-45

Clarida R, Gali J, Gertler M (2002) A simple framework for international monetary policy analysis. J Monet Econ 49:879-904

Clark TE (1999) The responses of prices at different stages of production to monetary policy shocks. Rev Econ Stat 81:420-433

Cooley TF, Hansen GD (1989) The inflation tax in a real business cycle model. Am Econ Rev 79(4):733748

Corsetti G, Pesenti P (2001) Welfare and macroeconomic interdependence. Q J Econ 116:421-445

Corsetti G, Pesenti P (2005) International dimensions of optimal monetary policy. J Monet Econ 52:281305

Dellas H, Tavlas SG (2005) Wage rigidity and monetary union. Econ J 115(506):907-927

Devereux MB, Engel C (2003) Monetary policy in the open economy revisited: price setting and exchange rate flexibility. Rev Econ Stud 70:765-783

Devereux MB, Engel C (2007) Expending switching versus real exchange rate stabilization: competing objectives for exchange rate policy. J Monet Econ 54:2346-2374

Devereux MB, Shi K, Xu JY (2007) Global monetary policy under a dollar standard. J Int Econ 71:113132

Erceg C, Henderson DW, Levin AT (2000) Optimal monetary policy with staggered wage and price contracts. J Monet Econ 46(2):281-314

Erceg C, Gust C, Lopez-Salido D (2010) The transmission of domestic shocks in open economies. In: Gali J, Gertler M (eds) International dimensions of monetary policy. Chicago University Press

Farhi E, Gopinath G, Itskhoki O (2014) Fiscal devaluations. Rev Econ Stud 81(2):725-760 
Feenstra RC (1998) Integration of trade and disintegration of production in the global economy. J Econ Perspect 12:31-50

Feldstein M (1992) The case against EMU. The Economist:19-22

Friedman M (1953) The case for flexible exchange rates in Essays in Positive Economics. Chicago University Press, Chicago

Gali J, Monacelli T (2013) Understanding the gains from wage flexibility: the exchange rate connection. Working Paper

Goldberg L, Tille C (2008) Vehicle currency use in international trade. J Int Econ 76:177-192

Goldberg L, Tille C (2009) Macroeconomic interdependence and the international role of the dollar. J Monet Econ 56:990-1003

Gopinath G, Rigobon R (2008) Sticky borders. Q J Econ 123(2):531-575

Hall R (2005) Employment fluctuations with equilibrium wage stickiness. Am Econ Rev 95(1):50-64

Huang K, Liu Z (2006) Seller's local currency pricing or buyers' local currency pricing: Does it matter for international welfare analysis J Econ Dyn Control 30:1183-1213

Hummels D, Ishii J, Yi KM (2001) The nature and growth of vertical specialization in world trade. J Int Econ 54:75-96

Hummels D, Rapoport D, Yi KM (1998) Vertical specialization and the changing nature of world trade, vol 4. Federal Reserve Bank of New York Economic Policy Review, pp 79-99

Mundell R (1961) A theory of optimum currency areas. Am Econ Rev 51:657-665

Murphy KM, Shleifer A, Vishny RW (1989) Building blocks of market clearing business cycle models. NBER Macroeconomics Annual 4:247-287

Nakamura E, Steinsson J (2008) Five facts about prices: a reevaluation of menu cost models. Q J Econ 123:1415-1464

Obstfeld M, Rogoff K (1995) Exchange rate dynamics redux. J Polit Econ 103:624-660

Obstfeld M, Rogoff K (2001) Risk and exchange rates. Prepared for the conference in honor of Assaf Razin

Obstfeld M, Rogoff K (2000) New directions for stochastic open economy models. J Int Econ 50:117-153

Obstfeld M, Rogoff K (2002) Global implications of self-oriented national monetary rules. Q J Econ 117:503-535

Obstfeld M (2002) Inflation-targeting, exchange-rate pass-through, and volatility. AM Econ Rev PP 92(2):102-107

Schmitt-Grohe S, Uribe M (2012) Pegs and pain. Working Paper

Shi K, Xu JY (2007) Optimal monetary policy with vertical production and trade. Rev Int Econ 15(3):514537

Shi K, Xu JY (2010) Twin dollarization and exchange rate policy. J Int Econ 81:109-121

Sutherland A (2002) International monetary policy coordination and financial market integration. ECB Working Paper No:174

Taylor J B (1999) Staggered price and wage setting in macroeconomics. In: Taylor JB, Woodford M (eds) Handbook of macroeconomics, vol 1. Elsevier, pp 1341-1397

Wang C Zou HF (2013) On the efficiency of monetary and fiscal policy in open economies. Annals Econ Finance 14:179-206

Yi KM (2003) Can vertical specialization explain the growth of world trade J Polit Econ 3(1):52-102

Yi KM (2010) Can multistage production explain the home bias in trade Am Econ Rev 100(1):364-393 